\title{
Professor McMurray and the School of Jurisprudence
}

\author{
Alexander Marsden Kidd*
}

THE legal literature of the past decade has been filled with the realists accuse their opponents of assuming the eternal validity of unproved and unprovable hypotheses and by a process of verbal manipulation drawing conclusions which in their application contradict the facts of experience, common sense, and justice. The conceptualists retort by characterizing realism as visceral jurisprudence, the law depending not on principles but upon whether the judge's breakfast agreed with him the morning he rendered a particular decision. Each school ridicules the absurdities of the other, but neither gives sufficient critical analysis to the validity of its own assumptions.

To Professor McMurray such a controversy must seem meaningless, as each view contains some truth but neither alone nor taken together the whole truth and nothing but the truth. It would hardly be possible for one of his experience to believe that life could be included in a system of self-contained concepts. The impact of life itself has been too compelling. He was born in 1869 in that portion of San Francisco affectionately known in later years as "south of the slot." The city itself was a living contradiction of the formulas which men had developed and by which they lived in other communities. Richard Henry Dana, Jr., in his chapter from Two Years Before the Mast, entitled "Twenty-four Years After," pictures vividly the modern city grown up almost over night composed of all the peoples of the earth, possessing something of the magic enchantment of the Arabian Nights. It was this bizarre city of contrasts and contradictions that fired the indolent genius of Bret Harte. It was not as in other migrations the contact of different peoples, eacl preserving its own law, but in the struggle for gold every individual was out for himself. Rugged individualism was a reality. To live in such a city required a tolerance and recognition of the practical limitations of 'personal or group beliefs and practices. In such an environment an unchanging rule of law could not square with the facts.

"A very great law teacher of the last generation said that 'all the available materials of the science of law are contained in printed books.' I think that

*Elizabeth Josselyn Boalt Professor of Law, University of California. 
almost any practitioner would deny this. The distinguished lawyers and judges who in our pioneer history first laid down the law respecting the appropriation of waters certainly did not extract their principles from printed books, but had read rather deeply in the great book of human nature."1

"In theory the development of the law is through the application of the rules of formal logic to facts and established principles found in legislation or judicial precedents. In reality it is the result of human forces of which the personalities of the judges are not the least important."2

This thought he develops by showing the influence of Stephen J. Field in bringing about in California the adoption of the codes of his brother, David Dudley Field. It is further shown by contrasting the law as developed by Mansfield, the associate of the wits and the merchants, with that of his successor, Lord Kenyon, "the faniously ignorant" upholder of the privileges of the landed classes of the eighteenth century. It can be said of McMurray as he said of Field: ${ }^{3}$

"The theory of an unchanging science of law, of an artificial perfection of reason has to be reconciled with that of the theory that the judge shall not in all cases 'blindly' follow precedent. Fortunately for the pioneer State, Field possessed that respect for the system of the common law which every true lawyer must possess; fortunately also he had a learning in the law rivalled by few American judges of his day. But most fortunate of all, his active hife had been a part of the life of the State, and he had the rare power of translating life into law. If law is ultimately a product of social and economic forces, it is through great personalities, such as that of Field, that these forces must find their expression.

"Bagehot in his essay on Macaulay speaks of men who 'think literature more instructive than life.' 'There is a whole class of minds,' he says, 'which prefers the literary dehineation of objects to the actual eyesight of them. To some life is difficult. An insensible nature, like a rough hide, resists the breath of passing things; an unobservant retina in vain depicts whatever a quicker eye does not explain. But anyone can understand a book; the work is done, the facts observed, the formulae suggested, the subjects classified.'

"Field's mind was the antithesis of all that is described by Bagehot as characteristic of Macaulay. It was a first-hand, not a second-hand mind; it was one not fed on pre-digested food; it was that of the man of affairs dealing with things of the mind, not that of the closet student dealing with affairs. Field looked at hife directly; he required no smoked glasses."

1 McMurray, Changing Conceptions of Law and of Legal Institutions (1915) 3 CaIIF. L. Rev. 441, 455.

${ }^{2}$ McMurray, Field's Work as Lawyer and Judge in California (1917) 5 CALIF. L. REv. $87,90$.

3 Ibid. at 106. 
One more quotation serves to illustrate the changes in rule through experience:

"Perhaps there are fields other than that of procedure where the doctrine of the binding force of judicial precedents may well be dimimished. The field of constitutional interpretation would seem to be one of these. I have been told that the Supreme Court of the United States no longer follows the constitution but has adopted Mr. Dooley's ideas. It would seem to me that the more recent decisions of that court under the Fourteenth Amendment are, on the whole, getting nearer to the reasonable construction of the language of that famous amendment than did their predecessors. That it is depriving a banker of his property or liberty without due process of law to make him a guarantor of other bankers in his state would seem to require a very pecular construction to be placed upon the words 'deprive,' 'property,' 'liberty,' and 'due process of law.' We may not personally like that sort of a law, and it may be very foohsh from an economic standpoint, but it would be stretching the meaming of language to hold that the Fourteenth Amendment was ever intended to embrace such a case. If former opinions justified the conclusion that the words of the amendment forbade a state from committing economic suicide, then let us do as did the Italian humanists in the fifteenth century, go back to the sources, disregard comments and read the original. If some lawyers criticize the court for its reversal of views concerning the police power with respect to the 'property' clause in the Fourteenth Amendment, a very respectable body both of lawyers and laymen criticize it, and with far more reason, it is submitted, for its attitude on the 'liberty' clause in the same amendment. It may be very desirable-I do not say that it is-that a baker should bave the right to work as long as he pleases, or that an employer should have the right to discharge a workman because he belongs to a labor umion, but to hold that these rights are guaranteed by that clause of the Constitution that says that a man shall not be deprived of life, hiberty, or property, without due process of law, is putting a very strange construction upon the word 'liberty,' especially considering its context. One would think that in the phrase respecting deprivation of 'life, liberty or property,' 'liberty' merely meant freedom from constraint, but the authorities hold otherwise. The whole battle between the majority and the minority of the court upon this crucial question hinges in its ultimate analysis upon the question whether or not the rule of stare decisis should be followed in all of its consequences. The rule of the binding force of precedent should have, it is submitted, less force in this class of cases than in almost any other. It seems absurd to claim that one has acquired rights relying upon the unconstitutionality of a statute; it is a very different thing, of course, where he has acquired rights relying upon its constitutionality."4

No, this was not written in 1940 but twenty-five years ago.

Professor McMurray prepared for college in the Urban School

4 McMurray, op. cit. supra note 1 , at 448. 
in San Francisco, a private school from which was graduated a number of men distinguished in the state and nation. The love of the Latin classics was instilled without the pedantry of scholastic gloss. The real meaning of the term "humanities" may be appreciated when imparted by a teacher who felt their human appeal even if occasionally there was in the teacher a little too much devotion to the Falernian from which Horace derived his inspiration. The old San Francisco had many such devout worshipers. Unlike Boswell's father, who had a contempt for modern literature, McMurray's favorites have always been those who have carried on the human side of the classics such as Lamb, Thackeray, and Stevenson.

In the University he was the most distinguished scholar of his class, 1890. His study of history in the University and afterwards was so outstanding that it brought him an offer of a professorship of legal history in one of the great law schools in the country. His devotion to history and literature, however, did not lead him to retire to the ivory tower for the worship of the muses. History for him was life in action, and the lesson is summed up in the words of Holmes: "The life of the law has not been logic: It has been experience."

Fortunately, after graduation from the University, in his legal education in Hastings College of the Law he did not come under the influence of dominating theorists, but was free to develop his own philosophy from the changing legal panorama in which he soon became an actor. The closing years of the nineteenth century saw the change from the simplicity of the nineteenth to the complexity of the twentieth century. The elevator, the telephone, and the typewriter were already in use. The shrewd old senior partner in the office in which McMurray spent his early years in practice came to California in pioneer days from Massachusetts, where he had tried his first case against Daniel Webster. He continued, however, to wear the tail coat and high boots, wrote out his papers in longhand, ignoring the stenographer and typist, and kept his money not in a bank but in gold coin in an office safe which would have presented but a slight obstacle to an enterprising burglar. In his desk were his dueling pistols which on one occasion he came very near using against the redoubtable Judge Terry. Such anger, however, was seldom aroused and only for important issues. At other times he was a genial comrade. Those were the days when the fraternal spirit of the older members of the profession was fostered and mellowed by frequent adjournments to the shrines Montgomery Street provided for that purpose. 
The American lawyer combining the functions of advocate and solicitor, who keeps up with the cases decided in his jurisdiction and applies them to the actual problems of his clients, is not likely to over-emphasize the "bloodless abstractions" of a conceptual jurisprudence. Twice in those days McMurray went through all of the California Reports, page by page.

It must not be thought, however, that he subscribes to the false analogy of the natural sciences and believes that with statistical apparatus facts, emotions, and other data can be put into test tubes, weighed, measured, and analyzed, and thereby law be understood and made predictable. The life is killed in the process. One whose philosophy recognizes the difficulty of expanding our limitations in the search for truth will change his judgments frequently as different aspects are presented to view. Nevertheless, in the scheme of things relatively fixed principles both for good and for evil play a part. All is not mere chance.

"So rapid have been the changes that our greatest living practical jurist, Mr. Justice Holmes, has said, 'To liave doubted one's own first principles is the mark of a civilized man.' But because he may sometimes doubt his first principles, the lawyer knows that he must not abandon them merely for that reason. He knows too well that most things in this life depend upon presumptions, and he recognizes that the mere fact of the existence of a rule or an institution places upon those attacking it the burden of proof. "The science of jurisprudence, the pride of the liuman intellect, whicll with all its defects, redundancies and errors, is the collected reason of ages, combining the principles of original justice with the infinite variety of human concerns,' as Burke terms it, is not to be abandoned because a few sliallow critics exaggerate here and there a casual fault or a special instance. We know that our civilization, our most precious rights and possessions, owe their being to our law."

In 1902 McMurray became a lecturer and in 1903 a professor in the newly created School at Berkeley, being Dean from 1923 to 1936. He gave to the School his full time during those years except for an occasional trip to Europe or a visit to another school. He kept in touch with practice by participating in a limited number of important cases, by civic service such as that involved in the Alameda County Charter and in the state constitutional commission, also in legal services as President of the Association of American Law Schools, member of the Executive Committee of the American Law

s Ibid. at 458 . 
Institute, California Annotator to the Restatement of Conflicts, and many other activities.

The School was founded by William Carey Jones on broad foundations of history and jurisprudence. These foundations were enlarged by McMurray, and there was added the close connection with California law and the profession. It is the hope of his colleagues that he will continue to adorn the temple of which he was one of the architects and that it may prove a more enduring monument than the bronze, steel, and gramite of Boalt Hall. 